\title{
Academics in business mix poorly
}

\section{Academic institutions have been unwarrantably slow in coming to grips with the their members' involvement with commercial companies, hazarding their main goals in the process.}

THE age of our innocence was a long time ago, but that does not absolve the academic research community from the charge of cynicism in the pursuit of the financial benefits of research. The question of what is proper has come to a head again with the fuss in Washington last week about access by academics to the sequences of human gene tags accumulated by two US companies, The Institute for Genome Research (TIGR; proprietor J. Craig Venter) and Human Genome Sciences (HGS) Inc., with financial and scientific support from SmithKline Beecham. But it is a recurring dilemma.

In 1981, for example, over lunch in Cambridge, Massachusetts, Mark Ptashne, the Harvard professor, outlined one version of it. At the time, Ptashne's colleague Walter Gilbert was on leave from the university to function as president of Biogen Inc., then based in Geneva. Ptashne's ambition was to set up a company that would do similar things, but perhaps better. (Genetics Institute, as the company became, has indeed been a success.) Ptashne's difficulty was how to acknowledge the university's implicit but unquantifiable contribution to anything that might come of his plan. His solution was to offer 10 per cent of the equity to Harvard. Harvard declined the offer.

More than 30 years earlier, at the University of Manchester, England, the same issue arose in a different context, and was instinctively fudged. The late F. C. Williams, professor of electrical engineering, had interested Ferranti Ltd in building an electronic computer, an advanced machine for 1947. Long before the idea that software might enjoy copyright protection (and before the notion of an operating system had surfaced), the late Alan Turing dragooned those in the university who could into writing elementary library programmes.

In all the excitement, nobody seemed to worry about his or her intellectual property. For one thing, it was fun. For another, it was generally understood that if the enterprise succeeded, the university would be blessed with a decent computer science department (which happened anyway). And Ferranti would no doubt have become even more generous with loans and gifts of electronic and microwave equipment. It is a pity that so little came of the enterprise.

That was the age of innocence. Academics knew that their first responsibility was to students, their second to research and that it was also in the public interest that they should do what they could for industry, preferably local industry, which could then be tempted to support the university as a whole. The understandings were implicit, but almost bankable. Now, there are contracts and memoranda of understanding about the ownership of intellectual property.

That is inevitable, but raises difficulties for academic institutions and also for governments, now almost united in their exhortation to academics that industrially relevant bright ideas are the best. The trouble is that, while the climate has changed, the goals of academic institutions have not. Are not students the first claim on an institution's responsibility? And then research whose temper will improve the quality of teaching and even be part of it (where graduate students are concerned)? As external subventions shrink, of course, there are many legitimate worries that academically purposeful research will be unduly cut back.

What, in those circumstances, should guide an academic institution's discharge of the general responsibility of the research community towards industry? The obvious first principle must be that nothing should interfere with the education of students, nor with research planned to that end. After all, successful industries usually say that they look to universities first and foremost for able and well-educated young people. (It is the lame ducks who look for patent licences instead.) Yet the conditions that must be satisfied by academics' industrial activities help to ensure that results are hardly ever discussed at universities.

Instead, there are discussions on questions such as the amount of time an academic researcher may legitimately spend working as a consultant for an industrial company, for a government or even for an international agency. Academic equality then ensures that the agreed rule will apply to all. Even the question of whether a consultancy will impair a person's capacity to give impartial advice to all and sundry is not taken up. Indeed, the nature of consultancy agreements is not habitually disclosed, certainly not to the close colleagues who may, nevertheless, be called upon to take a class that an over-burdened consultant-academic has to abandon at short notice.

But that is the small change of academic business. The road to riches demands more daring. To found a commercial company is a now commonplace route. But academic institutions are curiously and even culpably innocent of the implications. It is not simply that chairmen, chief executives and board members of companies have overriding fiduciary obligations to their shareholders that can be potentially overwhelming of their academic responsibilities, but that the affairs of a new company are an incorrigible thief of the imagination of all those caught up in them. At least for a time, the academic entrepreneur will be a less dedicated teacher.

Yet few academic institutions have thought it worthwhile to have formal regulations on this subject. That is in stark contrast to what happens in commercial life, where an employee of one company can be a director of another only with the formal consent of his or her employer. The objective is to avoid intolerable conflicts of interest or intolerable external demands on time and energy. Are academic researchers somehow exempt from these conflicts? Certainly not in the opinion of those companies now said to maintain databases of the commercial connections of prominent academics in biotechnology and molecular genetics.

This is where government exhortations often ring false. Newly founded companies are small businesses, and small businesses are the engines of economic growth, even though most of them fail. So the climate has changed, and academic entrepreneurship is blessed. Nobody seems to have calculated the damage that may indirectly be done to the quality of teaching on which business, or at least successful business, also depends.

These complaints do not apply directly to research contracts let by industrial companies to academic departments, at least when the arrangements for the publication of the outcome do not prejudice the impartiality of the academics and students who are involved. There, the question is whether the project is one that will provide students with the challenge and the experience they need in preparation for a research degree. It may, for example, be a matter of argument whether a person who works out a qualitycontrol routine in the manufacture of silicon chips can fairly earn a PhD in physics. Given the general eagerness of academic institutions for external income, even these questions are too little discussed.

The mess in molecular genetics has arisen because there are so many opportunities, because they seem to lie just within reach and because the rewards of occasional success appear to be so great. How can academic institutions hope to hold the line against such temptations? There is, of course, a market solution: buying out the would-be entrepreneurs. Sadly, few institutions are well-placed enough to follow it, but that does not mean that they can let the problem find its own solution.

John Maddox 